\title{
Critical review of the article published by Andreas May (2006): "Radiastraea (Anthozoa, Rugosa) from the Emsian and Eifelian (Devonian) of Aviados, Northern Spain"
}

\author{
FRANCISCO SOTO
}

Soto, F. 2007. Critical review of the article published by Andreas May (2006): "Radiastraea (Anthozoa, Rugosa) from the Emsian and Eifelian (Devonian) of Aviados, Northern Spain”. Bulletin of Geosciences 82(3), 291-292. Czech Geological Survey, Prague. ISSN 1214-1119. Manuscript received February 28, 2007; issued September 30, 2007. DOI 10.3140/bull.geosci.2007.03.291

Francisco Soto, Departamento de Geología, Universidad de Oviedo, 33005 Oviedo, Spain; fsoto@geol.uniovi.es

A. May's work (2006), titled "Radiastraea (Anthozoa, Rugosa) from the Emsian and Eifelian (Devonian) of Aviados, northern Spain", published in the Bulletin of Geosciences, volume 81(3), pp. 151-162, has shown important mistakes in the geographical location and stratigraphical interpretation of the outcrops studied (El Cueto and Sierra Carro, Aviados, NW Spain), which lead to very doubtful palaeogeographical conclusions. In a region like the Cantabrian Zone with very complex tectonics (especially in the Aviados area due to the Sabero-Gordon fault), the author's analysis regarding the rugose coral and other fossil samples with respect to the formation to which they belong and, consequently, the corresponding age (Santa Lucía Formation, late Emsian-earlier Eifelian or Portilla Formation, Givetian in age) is very superficial and of poor scientific foundation.

As co-author of the report of the Geological Map where the fossil samples described in the above-mentioned paper (Boñar, sheet No. 104) were collected and as a specialist on the coral fauna from the Devonian in the Cantabrian Mountains (NW Spain) for more than 30 years, I want to put forward my opinions on discrepancies on the origin and age of the material collected by Almela \& Revilla (1950) subsequently accepted by May (2006). In order to eliminate any possible misunderstanding, I recommend consulting the information on the geographical and stratigraphical situation of the outcrops in the National Topographical Map of Spain, scale 1 : 25 000, Boñar sheet (104-III: Robles de la Valcueva) edited by the Instituto Geográfico Nacional de España (Ministerio de Fomento), in 1997 and the Geological Map of Spain, scale 1 : 50 000, Boñar sheet (No. 104, 14-07), edited by the Instituto Geológico y Minero de España (Lobato et al. 1984).

\author{
Geographical considerations \\ and stratigraphical interpretation
}

\section{El Cueto outcrop}

The geographical location of this outcrop has been well specified by Almela \& Revilla (1950, p. 50) and approved by the author of the paper (May 2006, p. 152).

The stratigraphical analysis was, according to the latter author (p. 152), based on the assumed presence of the Spirifer cultrijugatus (late Emsian-early Eifelian) quoted in the faunal list by Almela \& Revilla (1950, pp. 50, 51). I agree with the author that the above-mentioned species, or any other of the same genus, cannot be easily misunderstood. But this analysis could be based equally on other species from the same list, such as Orthis dumontiana (= Cariniferella dumontiana), of Frasnian age, or on Aviadocrinus sampelayoi (= Cupressocrinites sampelayoi), Givetian in age (see Breimer 1962, p. 160), or even based on the numerous Phillipsastreidae cited in the list, also of late Givetian. According to this, the heterogeneous character of the sample is observed as probably composed of loose specimens, even coming from different nearby areas and thus the material is without a stratigraphical context. However, the majority of the cited specimens are Givetian, and, consequently, mainly come from the Portilla Formation and not from the Santa Lucía Formation (late Emsian-early Eifelian), as assumed by Almela \& Revilla (1950, p. 51) and May 2006 (pp. 151, 152).

The El Cueto outcrop is located within a fairly continuous calcareous band of the Portilla Formation, on the southern limb of a small anticline, dated not only by brachiopods, crinoids and corals but also by conodonts (see Geological Map of Boñar, No. 104, Lobato et al. 1984, and Report, Truyols et al. 1984, pp. 23, 24).

\section{Sierra Carro outcrop}

Almela \& Revilla (1950, p. 51) located this outcrop $1 \mathrm{~km}$ $\mathrm{W}$ of Aviados, on a hill at a height of $1.197 \mathrm{~m} \mathrm{~N}$ of the El Cueto outcrop. These geographical data do not correspond to those of the Sierra Carro outcrop (= Sierra de los Carros, 
see National Topographical Map of Spain, Boñar sheet, 104-III: Robles de la Valcueva, 1997), situated three km SW of Aviados, but to those of the Pico Cutión. The geographical position and topographical height of the latter coincide with those indicated by Almela \& Revilla (1950, p. 51) for the Sierra Carro outcrop (see previously mentioned Topographical Map). Thus, the geographical location of the Sierra Carro according to Almela \& Revilla (1950) is incorrectly stated and, as a consequence, also by May 2006 (p. 152, 157).

In the Pico Cutión, a calcareous band crops out, fitted between two satellite faults related to the Sabero-Gordón fault. This outcrop constitutes the northern limb of the same anticline to which the El Cueto one belongs. Consequently, this calcareous band corresponds to the Portilla Formation and not to the Santa Lucía Formation (late Emsian-early Eifelian), as indicated by the already-mentioned authors (op. cit.). The Givetian age of this outcrop is based on the same findings as those cited in the El Cueto outcrop.

\section{Systematical considerations}

The species determined and described by May 2006 (pp. 153-156) as Radiastraea arachne Stumm, 1937, comes from the El Cueto outcrop (Portilla Formation, Givetian). In my opinion, it is an undetermined species of the genus Phillipsastrea (the two thin sections of the fig. 2B, C do not allow us to reach a definite species identification). The fusiform septa in the inner part of the dissepimentarium (fig. 2B) and the tabularium structure, with incomplete, vesicular and generally convex tabula (fig. 2C) are characteristic features of the genus Phillipsastrea (CoenAubert 2002, p. 26). On the contrary, the genus Radiastraea is characterized by thin, sometimes carinate septa (see Pedder 1964, pl. 72, fig. 3, pl. 73, figs 4, 5, and Oliver 1976, pl. 66, figs 1-3) and a tabularium structure consisting of incomplete, axially convex and periaxially very arched (concaves) tabula (see Pedder, 1964, pl. 72, fig. 2, pl. 73, fig. 2, and Oliver, 1977, pl. 66, fig. 4).

On the other hand, the two species described in the work in discussion as Phillipsastrea torreana torreana (pp. 156, 157, without illustration) and P. torreana minuta (pp. 157, 158, fig. 2D-F) show a corallite diameter, number of septa and tabularium diameter within the variability boundaries established by Coen-Aubert (2002, p. 30) for the species Phillipsastrea torreana.

In my opinion and taking into account the previous considerations, it can be deduced that the three species described by May (2006) would represent an undetermined species of the genus Phillipsastrea, and the two subspecies, P. torreana torreana and $P$. torreana minuta, represent only variation within the species P. torreana.

\section{Other remarks}

Surprisingly, in fig. 1 of the work, the El Cueto outcrop (letter E) is situated to the south of the road LE-626 whereas the correct location is to the north. To the south of this road only Mesozoic (Upper Cretaceous) and Tertiary rocks crop out (see Geological Map of Boñar, No. 104, Lobato et al. 1984).

Meanwhile, the author indicates that Almela \& Revilla (1950) used the term "Couvinian" (see p. 151) to establish the age of the colonial rugose corals collected from the El Cueto and Sierra Carro outcrops in the surroundings of Aviados. Nevertheless, Almela \& Revilla (1950, pp. 50, 51, Lam. III, fig. 5) did not use the term "Couvinian" but Eifelian.

Finally, I must not end this critical commentary without pointing out that the study of museum samples, as is the case, is very hazardous; every precaution must be taken especially if no strict control of the sample localities has been made.

\section{References}

Almela, A. \& Revilla, J. DE LA 1950. Especies fósiles nuevas del Devoniano de León. Notas y comunicaciones del Instituto Geológico y Minero de España 20, 47-60.

Breimer, A. 1962. A monograph of Spanish Palaeozoic Crinoidea. Leidse Geologische Mededelingen 27, 1-189.

Coen-Aubert, M. 2002. Nouvelles espèces du genre Phillipsastrea d'Orbigny, 1849 près de la limite Givetien-Frasnien dans le Tafilalt et le Ma'der au Maroc et notes sur des types espagnols. Coral Research Bulletin 7, 21-37.

Lobato, L., Garcia-Alcalde, J.L., RodrigueZ-Fernández, L.R., Sanchez De Posada, L. \& Truyols, J. 1984. Cartografía de la Hoja Geológica $n^{\circ}$ 104, 14-07 (Boñar), del Mapa Geológico de España, e. 1 : 50.000. Instituto Geológico y Minero de España, Servicio de Publicaciones del Ministerio de Industria y Energía.

May, A. 2006. Radiastraea (Anthozoa, Rugosa) from the Emsian and Eifelian (Devonian) of Aviados, northern Spain. Bulletin of Geosciences 81(3), 151-162.

OLIVER, W.A., JR. 1976. Noncystimorph colonial rugose corals of the Onesquethaw and Lower Cazenovia Stages (Lower and Middle Devonian) in New York and adjacent areas. U.S. Geological Survey Professional Paper 869, I-V + 1-156.

PedDER, A.E.H. 1964. Correlation of the Canadian Middle Devonian Hume and Nahanni Formations by tetracorals. Palaeontology 7(3), 430-451.

Truyols, J., Alvarez, F., Arbizu, M., García-Alcalde, J.L., GARCÍA-LóPEZ, S., MARTíneZ-Chacón, M.L., MÉNDEZ Bedia, I., Méndez-Fernández, C.A., MenéndeZ, J.R., SAnchez De Posada, L. \& Soto, F. 1984. Memoria explicativa de la Hoja Geológica $n^{\circ} 104$ (Boñar), del Mapa Geológico de España, e. 1 : 50.000. 77 pp. Instituto Geológico y Minero de España, Servicio de Publicaciones del Ministerio de Industria y Energía. 